\title{
Overwinter Storage of Walker Poplar Cuttings
}

by

\author{
W.H.Cram, ${ }^{1}$ and C.H. Lindquist ${ }^{2}$
}

\begin{abstract}
Rooting of cuttings was $\mathbf{8 2} \%$ after overwinter storage at $-2{ }^{\circ} \mathrm{C}, 73 \%$ after $+2{ }^{\circ} \mathrm{C}$ storage, and only $60 \%$ after being heeled-in outdoors. Budbreak after planting was earliest for the heeled-in cuttings and latest for those refrigerated at $-2^{\circ} \mathrm{C}$, but length of the subsequent top growth was similar for all storage treatments.
\end{abstract}

\section{Résumé}

Des boutures de peupliers de Walker, après avoir hiverné les unes en entrepôt à des températures de $-2^{\circ} \mathrm{C}$ ou de $+2^{\circ} \mathrm{C}$ et les autres en jauge à l'extérieur, ont eu les taux d'enracinement respectifs suivants: $82 \%, 73 \%$ et $60 \%$. Le débourrage après planification fut le plus précis chez les boutières en jauge et le plus tardif chez les boutières entreposées à $-2^{\circ} \mathrm{C}$. L'élongation subséquente de la pousse terminale a été cependant similaire quelque soit le mode d'hivernage.

\section{Introduction}

Hardwood cuttings of poplar have traditionally been stored overwinter by "heeling-in" outdoors on nurseries in northern regions. Unfortunately these cuttings break dormancy during prolonged warm periods in early spring, unless lifted and planted. However, plantings must frequently be delayed, due to unfavorable site conditions or conflicting nursery operations, and as a result the cuttings root poorly.

Refrigerated storage facilities have been reported by Hocking (1972) to be utilized by most nurseries in Canada and the United States for conifer seedlings each spring, but only by a few for overwinter storage. Cram and Lindquist (1983) found rooting of hardwood poplar cuttings after refrigerated storage at $-4^{\circ} \mathrm{C}$ equalled that for those heeled-in overwinter.

The present study evaluates several methods of refrigerated storage specifically for cuttings of the Walker poplar clone, (Populus x deltoides Bartr. cv. 'Walker'). This clone was found outstanding for shelterbelt and amenity purposes in the prairies, on the basis of test plantings by Cram (1960) and Lindquist et al. (1979). Walker poplar was originally designated as FNS 44-52, when selected by John Walker at the Indian Head Forest Nursery Station in 1944, but has since been officially identified and registered by Roller et al. (1972).

\section{Materials and Methods}

One-year-old shoots were harvested on November 14 in 1977 from "cutting beds" of Walker poplar. These shoots were made into cuttings $15 \mathrm{~cm}$ in length, but only those from the middle part of shoots with basal diameters of 10 to 18 $\mathrm{mm}$ were utilized for the study. All cuttings were dipped in a water suspension of Captan $50 \mathrm{~W}$ fungicide $(33 \mathrm{~g} / \mathrm{L})$ then airdried for one minute, as recommemded by Carlson and Lindquist (1969) for storage of cuttings.

Six hundred cuttings were tied in bundles of 25 and heeledin out-doors for the winter to provide a check treatment. However, these were lifted early on May 8 in 1978, sealed

\footnotetext{
${ }^{1}$ Superintendent from 1958 to retirement in 1977, Tree Nursery, PFRA, Indian Head, Saskatchewan.

${ }^{2}$ Technician for nursery propagation research from 1963 to present.
}

in poly bags and stored at $2^{\circ} \mathrm{C}$, to maintain dormancy until planted. Six lots of 600 cuttings were stored in $20 \mathrm{~cm} \times 20$ $\mathrm{cm} \times 60 \mathrm{~cm}$ boxes, which were lined and sealed with $4 \mathrm{ml}$ polyethylene. For two of these boxes, the cuttings were placed vertically with the bases on a $0.4 \mathrm{~cm}$ layer of moist $(10 \%)$ moss, prior to sealing. Three of the boxes of cuttings were stored overwinter at $-2^{\circ} \mathrm{C}$ and three at $+2^{\circ} \mathrm{C}$, although one of each was transferred to $+5^{\circ} \mathrm{C}$ storage for the last two weeks, as detailed in Table 1.

All cuttings were removed from storage and planted by hand on May 23 in 1978 with metal dibbles in a prepared nursery site. The planting was a randomized block design with 100 cuttings per plot for each of the seven storage treatments with five replications. Chloroxuron herbicide was applied as an overall spray at $5.6 \mathrm{~kg} / \mathrm{ha}$ immediately after planting and incorporated by irrigation with $2.5 \mathrm{~cm}$ of water.

Moisture content of the cuttings following the seven storage treatments was determined on May 23. This was calculated as a percentage of the dry weight for five samples of two cuttings after oven-drying at $100^{\circ} \mathrm{C}$ to a constant weight after 24 hours. Dates of budbreak or first flush of top growth were recorded biweekly for the planted cuttings from May 29 to July 7 and the index rate ${ }^{3}$ calculated for each storage treatment and replication. Length of the top growth for cuttings of all treatments and replications was recorded on September 25. All plants were lifted on October 20 and the number of rooted cuttings recorded. All data were subjected to analyses of variance to determine the significance of mean differences by Duncan's multiple range test with the results listed in Table 1.

Table 1. Moisture content, flush rate, top growth and rooting for hardwood cuttings of Walker poplar following seven overwinter storage treatmens.

\begin{tabular}{|c|c|c|c|c|c|}
\hline \multicolumn{2}{|c|}{ Storage treatments } & \multirow{2}{*}{$\begin{array}{c}\text { Moisture } 1 \\
\text { Content }\end{array}$} & \multirow{2}{*}{$\begin{array}{c}\text { Flush }^{2} \\
\text { rate }\end{array}$} & \multirow{2}{*}{$\begin{array}{c}\text { Top }{ }^{3} \\
\text { growth }\end{array}$} & \multirow{2}{*}{$\begin{array}{l}\text { Rooting } 4 \\
\text { capacity }\end{array}$} \\
\hline Temperature & Cover & & & & \\
\hline$\left({ }^{\circ} \mathrm{C}\right)$ & & $(\%)$ & (Index) & $(\mathrm{cm})$ & $(\%)$ \\
\hline-2 & Poly & $108 d^{7}$ & $.64 c$ & $100 a$ & $82 a$ \\
\hline-2 & Poly + moss & $113 \mathrm{~cd}$ & $.62 c$ & $97 a$ & $77 a$ \\
\hline-2 to +5 & Poly 5 & $108 d$ & $.70 b$ & $103 a$ & $74 a b$ \\
\hline+2 & Poly & $108 d$ & $.64 c$ & $105 a$ & $73 a b$ \\
\hline+2 & Poly + moss & $118 b c$ & $.67 \mathrm{bc}$ & $102 a$ & $73 a b$ \\
\hline+2 to +5 & Poly 5 & $123 b$ & $.72 b$ & $99 a$ & $71 a b$ \\
\hline Heel-in & Soil 6 & $136 a$ & $.82 a$ & $105 a$ & $60 \mathrm{~b}$ \\
\hline
\end{tabular}

${ }^{1}$ Moisture content as a percentage of the oven-dry weight for 5 samples of 2 cuttings

${ }^{2}$ Rate of flush index, the earlier growth the larger the value

3Length of top growth in centimeters on September 25

${ }^{4}$ Rooting capacity as percentage for 5 replications of 100 cuttings

${ }^{5} \mathrm{Cuttings}$ stored at $5^{\circ} \mathrm{C}$ for 2 weeks prior to planting

${ }^{6}$ Cuttings lifted May 8 and stored at $2^{\circ} \mathrm{C}$ until planted

${ }^{7}$ Values followed by same letters are not significantly different

\section{Results and Discussion}

Moisture content and rooting capacity of cuttings differed significantly for storage treatments but not the top growth (Table 1). Moisture content of cuttings was significantly highest at 136 percent after being heeled-in overwinter, at an intermediate level after the $+2^{\circ}$ to $+5^{\circ} \mathrm{C}$ storage, but

\footnotetext{
3Index rate: $\frac{Y_{1}+Y_{2}+\ldots . . Y Y_{i} \text {, where } Y}{(Y i)(N)}=$ the number of flushed cuttings recorded on any specific date, $\mathrm{Yi}=$ the number flushed on last record date, and $\mathrm{N}=$ the
} number of dates records taken. 
significantly lowest and similar for all remaining $+2^{\circ}$ and $-2^{\circ} \mathrm{C}$ storages. On the other hand, length of the top growth of rooted cuttings was essentially the same for all storage treatments.

Rooting capacity of cuttings was greatest $(82 \%)$ after refrigerated storage at $-2^{\circ} \mathrm{C}$, but this was significantly superior only to that recorded for the heeled-in storage. Rooting of 73 percent, which was recorded after storage at $+2^{\circ} \mathrm{C}$, was not significantly different than for the $-2^{\circ} \mathrm{C}$ nor the heeled-in storage treatments. In addition rooting of cuttings was not improved either by storage with moist moss nor by raising the temperature to $5^{\circ} \mathrm{C}$ for two weeks prior to planting.

Similar results for moisture content but variable results for rooting were reported by Cram and Lindquist (1983) for hardwood cuttings of Tristis and Northwest poplar clones after five overwinter storages. They found moisture content of cuttings was highest (142 and 152\%) after heeled-in storage for both clones, but less and equal for refrigerated storages at $+2^{\circ} \mathrm{C}$ and $-4^{\circ} \mathrm{C}$. On the other hand, the rooting of Northwest cuttings was similar for all storage treatments, whereas rooting of Tristis cuttings was reduced by refrigerated storage at $+2^{\circ} \mathrm{C}$.

Callus formations were recorded on Walker poplar only for those cuttings heeled-in overwinter. These were probably produced by the high level of moisture $(123 \%)$ for the cuttings as suggested by Bloomberg (1964). Whereas the inferior rooting $(60 \%)$ for heeled-in cuttings suggests that callus formations may not be essential for the rooting of Walker poplar cuttings.

Length of the top growth for cuttings on September 25 was not influenced by any of the storage treatments, but 13 percent of those manifesting top growth failed to develop roots by October 20 . This differential varied from a low of eight percent for cuttings overwintered at $-2^{\circ} \mathrm{C}$ to a high of 23 percent for those heeled-in. Thus top flush or growth of poplar cuttings, which was utilized by Petersen and Phipps (1976) as a criterion for rooting, proved unreliable for evaluating field plantings of cutting storage treatments.

Rooting capacity of Walker (44-52) poplar was reported by Cram (1960) to be 87 percent, when the cuttings were heeledin outdoors overwinter, then lifted and planted immediately on May 8 in 1951. Whereas, the rooting capacity of Walker poplar after heeled-in storage in the present study was only 60 percent, when the cuttings were lifted on May 8 and stored at $2^{\circ} \mathrm{C}$ until planted May 23 . However, rooting capacity for the 1951 study was erroneously evaluated as the percentage of planted cuttings with top growth, which was 83 percent for the present study. Thus the rooting was evidently similar after heeled-in storage for the two studies.

Budbreak or flush of top growth (Table 1) was apparently conditioned partly by moisture content and partly by storage temperatures of the cuttings. For example, the earliest flush of top-growth was recorded for the heeled-in cuttings, which had the highest moisture content after storage. The second earliest budbreak was recorded for cuttings of two treatments, those transferred from $-2^{\circ} \mathrm{C}$ and $+2^{\circ} \mathrm{C}$ to $+5^{\circ} \mathrm{C}$ for the two weeks prior to planting. In both cases the flush of top growth was significantly earlier than for those cuttings held at $-2^{\circ} \mathrm{C}$ and at $+2^{\circ} \mathrm{C}$ until planted. Nevertheless, the time of budbreak or flush apparently had no effect on length of top growth nor rooting capacity of cuttings.

\section{Conclusions}

1. The rooting capacity of Walker poplar was highest at $82 \%$ for hardwood cuttings sealed in $4 \mathrm{ml}$ poly and stored overwinter at $-2^{\circ} \mathrm{C}$.

2. Callus formations were recorded only for cuttings, which were heeled-in outdoors overwinter and had the highest moisture content, but manifested only $60 \%$ rooting.

3. Budbreak of planted cuttings, which was earliest for those heeled-in and latest for those stored at $2^{\circ} \mathrm{C}$, was not related to length of the top growth.

4. Length of the top growth of cuttings was not influenced by any of the overwinter storage treatments.

\section{References}

Bloomberg, W.J. 1964. Some factors in the development of callus in poplar cuttings. For. Chron. 40:509-511.

Cram, W.H. 1960. Performance of seventeen poplar clones in south central Saskatchewan. For. Chron. 36:204-209.

Cram, W.H. and C.H. Lindquist. 1983. Refrigerated storage for hardwood cuttings of willow and poplar. US For. Serv., Tree Planters' Notes (in press).

Carlson, L.W. and C. Lindquist. 1969. Poplar hybrid, storage breakdown, unknown cause. In, K.D. Hickey (ed.), Fungicide and nematicide tests, results of 1968., Amer. Phytopath. Soc. 24:93-94.

Hocking, D. 1972. Nursery practices in cold storage of conifer seedlings in Canada and the United States. US For. Serv., Tree Planters' Notes (in press).

Carlson, L.W. and C. Lindquist. 1969.Poplar, hybrid, storage of poplar clones at four sites in southern Saskatchewan. In, Fayle, D.C.F., L. Zsuffa and H.W. Anderson, (eds.). Poplar research, management and utilization in Canada. Proc. North Amer. Poplar Counc. Annual Meet., Brockville, Ont., Sept. 6-9, 1977. Ont. Min. Natur. Res., Forest Res. Inform. Pap. No. 102. Rept. 5:1-7.

Petersen, L.A. and H.M. Phipps. 1976. Water soaking pretreatment improves rooting and early survival of hardwood cuttings of some populus clones. US For. Serv., Tree Planters' Notes 27:12-22.

Roller, K.J., D.H. Thiabault and V. Hildahl. 1972. Guide to the identification of poplar cultivars on the prairies. Can. Dep. Environ., Can. Forestry Serv., Pub. No. 1311. 55p.
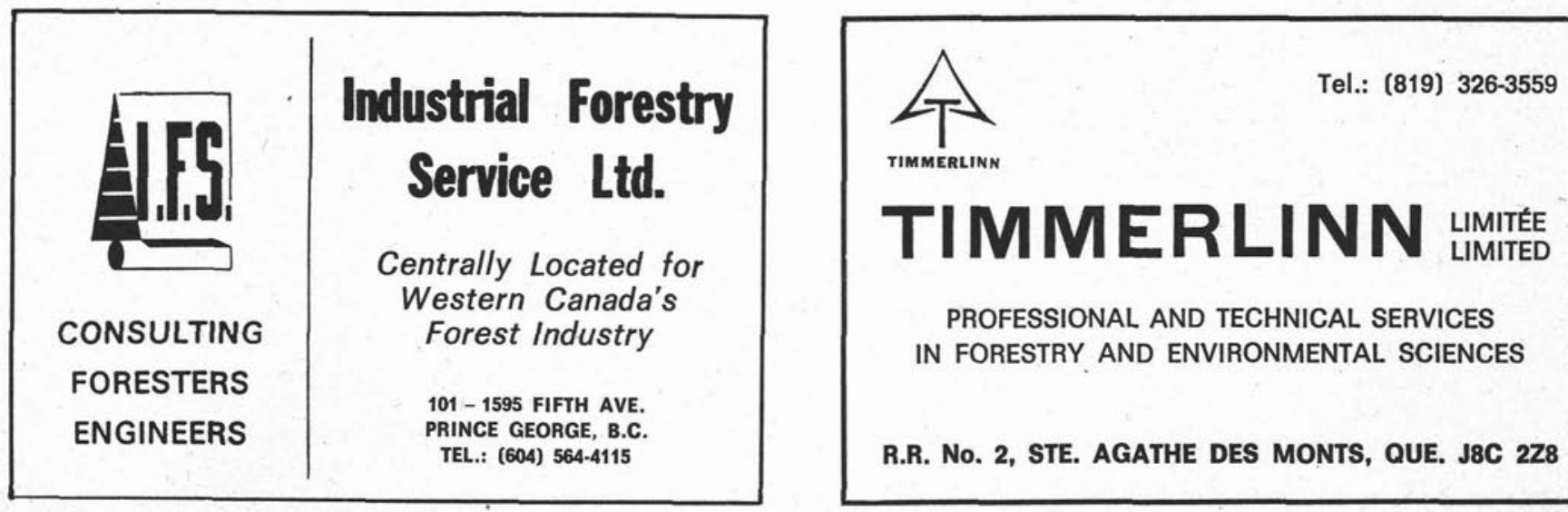
PROFESSIONAL AND TECHNICAL SERVICES IN FORESTRY AND ENVIRONMENTAL SCIENCES

R.R. No. 2, STE. AGATHE DES MONTS, QUE. J8C $2 Z 8$ 